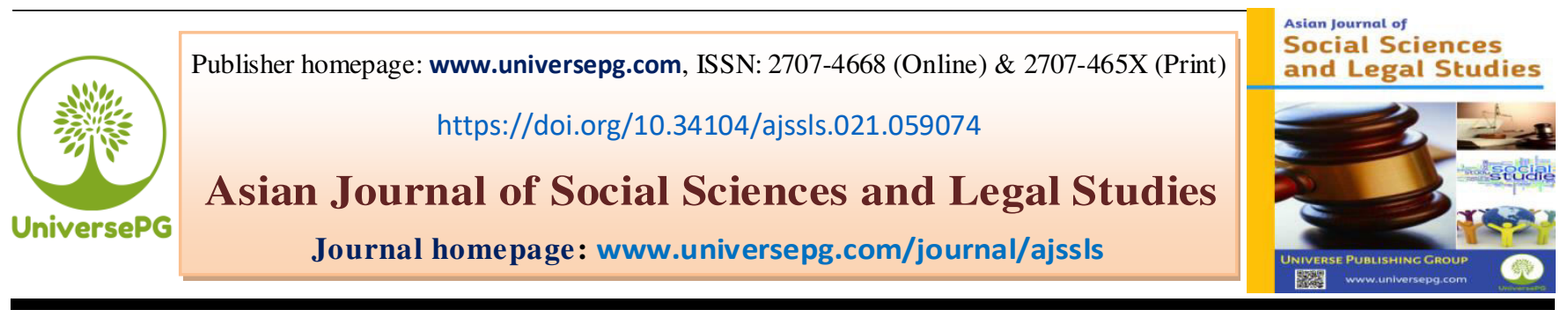

\title{
The Gateway to Well-being and Happiness: Re-defining Individualism, Voluntary Simplicity and Civilization
}

\author{
Habtamu Girma Demiessie $^{1 *}$, Md. Rasel Hossain ${ }^{2}$, and Sonia Shirin ${ }^{3}$ \\ ${ }^{1}$ Department of Economic Policy Analysis, Jigjiga University, Ethiopia; ${ }^{2}$ Dept. of Statistics, Noakhali Science and \\ Technology University, Noakhali, Bangladesh; and ${ }^{3}$ Dept. of English, Gono Bishwabidyalay, Dhaka, Bangladesh. \\ *Correspondence: ruhe215@gmail.com
}

\begin{abstract}
This article is an attempt to depict principles and philosophical lines so as to promote the well-being and happiness of people and communities. The principles of theoretical research govern the methods and tools of making analysis and inferences. In this regard, theories from positive psychology, behavioral \& institutional economics, sociology and anthropology were consulted. The study starts by reviewing the theoretical and empirical literature on the two interrelated concepts, well-being and happiness. Doing so, it looks into a systematic analysis into what factors are weighing in determining the well-being and happiness at individual and collective levels. In this regard, it identifies individualism, voluntary simplicity and civilization concepts key variables. With the benchmark being the conventional narratives, the study tries to characterize those concepts in a way that better appeals to pillars of well-being and happiness concepts. While making characterizations on individualism, voluntary simplicity and civilization, the study infers the drawbacks of the underlying constructs of the conventional understandings and come up with alternative ones in a way that better serve the affective and eudemonic well-being of people. In this regard, it came up with concepts of individualism-proper, a theoretical contribution of this work in redefining the concept of individualism in a better way to promote collective well-being and happiness. It also revisits the notion of voluntary simplicity in a way to appeal business of life and at all levels, from individual to societal to country level. As such, the paper tries to frame on the foundation of collective happiness and well-being by pinpointing for philosophical lines, depicting moral standards and/or principles that people shall pursue in their intra-personal and inter-personal relationships. The study further evokes the academia and policy regimes to consider why and how well-being and happiness issues should be the pinpoint of their respective endeavors.
\end{abstract}

Keywords: Happiness, Civilization, Simple style, Well-being, Voluntary simplicity, and Individualism proper.

\section{INTRODUCTION:}

For long economic literature has taken for granted material prosperity analogous to well-being. However, the practical realties were in contrast to those assertions. In the major capitalist societies of the world, lust for material glory, featured by over consumption. According to Jackson, (2008), over consumption which

UniversePG I www.universepg.com means a consumption which is justified neither by biological nor by social-economic considerations. In the long term a significant effect of overconsumption is quality of life deterioration confirmed by well-being paradox observed in industrialized countries (Hasan and Rupa, 2021). Accor-ding to this paradox the sense of happiness doesn't rise proportionally to the increase in income. It results from the fact that beyond a certain 
level of welfare the further income growth generates additional non-material costs like overwork, stress, permanent hurry, and lack of time to rest and to cultivate family and social relations. When an individual accepts current deficiency of life satisfaction trying to secure their own future and expecting to be happy in retirement thanks to their current sacrifice the "Deferred Happiness Syndrome" occurs (Ibid). Empirical evidence on what causes economic growth shifted focus in the late 1990s towards looking at the concept of well-being. Well-being is defined as when people simultaneously experience two states of emotions: the absence of the crippling elements of the human experience-depression, anxiety, anger, fear and the presence of enabling ones-positive emotions, meaning healthy relationships, environ-mental mastery, engagement, and self-actualization (Seligman and Csikszentmihalyi, 2000; Seligman, 2011).

Extensions to this work have focused on issues of trust within countries and on the importance of material and spiritual capital for people. Happiness and well-being are inalienable concepts for many reasons. For one, both entails on quality of life and subjective well-being (World Health Organization Quality of Life Group, 1995 and Diener, 2006). Indeed, happiness is normally defined as a positive affect but can also be thought of as a universal evaluation of a person's life satisfaction. As in the case of well-being, happiness is determined by economic and non-economic factors. The economic aspect of well-being includes people's access to wider socio-economic amenities like housing, education, health, income level, income inequality, unemployment at least within the context of growing economy (Diener, 2006; Camfield and Skevington, 2008).

Some of the non-economic aspects of well-being and/ or happiness are psychological, sociological, anthropological and political elements. From psychological perspective, referring recent developments in positive psychology, well-being of people is understood from two perspectives: hedonic well-being, but also includes eudemonic well-being (Weerakoon, 2020). Hence, Well-being is now understood not simply as positive emotions, but, rather, as thriving across multiple domains of life (Easterlin, 1974; 2013). From sociological point of view, poor are those are at risk of deprivation of, not only, material well-being, but also deprived of their social status and unable to fetch out of socio-cultural institutions. A sociological narrative of well-beings of people focuses on the workings of those institutions and how far people access them to serve their life in many ways. As such, social relations among family members, friends, and neighbors are important. Moreover, socio-demographic, economic, cultural, and political factors are worth considering while conceptualizing well-being of people. Despite growing academic interest on the concept of happiness, still those endeavors are inclined towards empirical analysis, where we lack less theories and general principles over the issue. This study is mainly aimed at filling this gap. Hence, it tries to devising a theoretical framework to deal with the concepts of well-being and/or happiness. As such, the conventional theoretical lines and principles that govern the academic and policy regimes that influence well-being of humanity in broader dimensions of life: economic, political, social, environmental, health, among others was questioned.

In doing so, the study makes critic on ideological foundation of the installed system of governance and/or rule of game to that influence life in all its dimensions, as depicted above. The paper is also laying the philosophical line and implied principles that better promote the material and spiritual prosperity of people and communities. More importantly the study tries to frame the workings of an order that better guarantee the well-being (happiness) of people.

\section{Objectives of the study}

The general objective of the study is to map out conceptual, philosophical, moral and practical foundations to promote collective well-being and happiness.

\section{Specific objectives}

In line with the general objective, the study will address the following: -

- Make review on theoretical/empirical literature on key variables/concepts/philosophical lines that govern the health or wellness of relationships at all levels: intra-personal, inter-personal and societal interactions.

- Redefine the concepts of individualism, voluntary simplicity and civilization in a way to best 
oil relationships, hence realize collective wellbeing \& happiness.

- Depict derivative philosophical lines/principles/ moral standards out of the three concepts-individualism, voluntary simplicity and civilizationthat ought to govern our behaviors and established institutions for the service individual and collective interests.

- Interpret how derivative philosophical lines/ principles/moral standards promote collective well-being \& happiness in all levels of interactions and/or all departments of life: intra-personal \& inter-personal, social, economic, politics and system of governance, among others.

- Emphasize the academic and policy regimes on why \& how essential behavioral/philosophical/ moral constructs be the focus of their respective endeavors so as to realize collective well-being and happiness.

\section{MTHODOLOGY:}

The study is largely relied on the principles of basic/theoretical/fundamental research. According to literature, the main motivation of basic research is to expand man's knowledge, not to create or invent something; in other words, basic research lays down the foundation for the applied science that follows. This is in fact go in line with the objective of the study. Hence, the theoretical framework to explain happiness of people is based on the two schemes of studying wellbeing and happiness of people. According to wider literature, well-being and happiness takes two forms: individual and collective level. While making analysis and interferences, the study borrowed theories from a host of social sciences and humanities. In this regard, positive psychology, social psychology, economic sociology, behavioral and institutional economics and economic theories were considered.

\section{Review of literature}

Basics of well-being - Well-being integrates purpose and meaning in life, including concepts such as competence, autonomy and engagement. Well-being encompasses two dimensions: objective as well as subjective well-being. Objective accounts of wellbeing rely on assumptions about human needs and rights. Sen, (1999) argues that these basic needs must be met in order for people to flourish and given the role the state has in providing these needs. Subjective wellbeing encompasses different aspects cognitive evaluations of one's life, happiness, satisfaction, positive emotions such as joy and pride, and negative emotions such as pain and worry (Stiglitz-Sen-Fitoussi, 2009).

Well-being has economic, psychological and social aspects. The economic aspect of well-being includes people's access to wider socio-economic amenities mainly education or elimination of poverty, inequality and unemployment within the context of growing economy. From psychological perspective, referring recent developments in positive psychology, wellbeing of people is understood from two perspectives: hedonic well-being, but also includes eudemonic wellbeing. Hence, Well-being is now understood not simply as positive emotions, but, rather, as thriving across multiple domains of life (Easterlin (1974; 2013). From sociological point of view, poor are those are at risk of deprivation of, not only, material well-being, but also deprived of their social status and unable to fetch out of socio-cultural institutions. Sociological narratives of well-beings of people focus on the workings of those institutions and how far people access them to serve their life in many ways.

\section{Measuring well-being of people}

Objective well-being- Objective measures have an important part to play in measuring national wellbeing. However, the objective approach does have limitations: for example, it requires researchers to decide what indicators are most important for monitoring and assessing the well-being of a nation before any assessment can be made. There is no single measure that can exhaustively capture the state of societies at a given point in time. Gross Domestic Product, Per capita Income (PCI) and/or Purchasing Power Parity (PPI) level of people has been considered as a conventional measure of socio-economic progress of people for long. Despite the fact that economic measures of progress provide useful information to governments, businesses, communities, and individuals, using GDP as the sole measure of national welfare would not be right from two dimensions: for one, not all market activities can be monetized. Secondly, it provides a limited depiction of individuals' quality of life and of 
societal prosperity (Diener et al., 2009; Stiglitz et al., 2010). If GDP is complemented with measures that capture changes in well-being, decision makers will have a more comprehensive, multi-dimensional, accurate portrayal of social progress. Hence, the need for alternative measures of well-being that provide valuable information to complement existing economic measures of national progress is of great importance.

Interest in happiness and well-being are not new in academia. Economists, psychologists, and political scientists have built up an impressive amount of research on happiness and well-being. Over the last two decades, there have been intensive academic endeavors on modeling for measures of subjective wellbeing of people. In addition to academic interventions, countries and international multilateral organizations has also been exerting efforts to device for measures of well-being. Perhaps, the earliest country-wise efforts to adopt for well-being measures is the case of Kingdom of Bhutan, where the country has used Gross National Happiness, rather than Gross Domestic Product, to design its institutional architecture and policies since 1972 (Adler, 2011). In recent years, in particular, many countries are eyeing for alternative schemes to know the well-being of their citizenry. For example, the former French President Nicholas Sarkozy established commission that provides evidences in his effort to recommend for world countries look new ways of approximating the welfare of their respective countries` people (Stiglitz et al., 2010).

The former Prime Minister of Britain, David Cameron, established a team of experts to that work on devising alternative measures of well-being of British people, Gross Domestic Well-being (GDW). In February 2016, the Prime Minister of the kingdom of United Arab Emirates (U.A.E), Sheikh Mohammed Bin Rashid Al Maktom, announced for establishing a ministry of happiness, tasked to planning, allocating resources and measure the welfare (well-being) of its people. There are collective efforts to erecting schemes or frameworks for measuring the well-being of people. In this regard, the Organization for Economic Cooperation and Development (OECD) has developed a manual document entitled Better Life Index detailing on a framework to advocate for well-being measures be used by its member states. In the year 2011, the United UniversePG I www.universepg.com
Nations adopted a resolution that encouraged member States "to pursue the elaboration of additional measures that better capture the importance of the pursuit of happiness and well-being in development with a view to guiding their public policies" (UN General Assembly Resolution A/65/L.86).

\section{Measuring subjective well-being}

As distinct from objective well-being, SWB has the advantage that it avoids the need for a priori assumptions about what constitutes a good life and also avoids paternalism (Waldron, 2010). This is because it asks individuals about their views about their own well-being and allows them to make their own assessment of their well-being. Existing empirical and theoretical literature to date depicts that there are three measures of well-being: Evaluative measures; Experience measures and Eudemonic measures.

Evaluative measure - Life evaluations capture a reflective assessment on a person's life or some specific aspect of it. This can be an assessment of "life as a whole" or something more focused. Such assessments are the result of a judgment by the individual rather than the description of an emotional state. Hence, evaluative measures ask the respondent to stand back and make an assessment of their life and, in the case of life satisfaction, score their life with regard to their satisfaction. Other types of evaluative measures include the Cantril ladder of life measure which asks respondents to imagine a ladder where the bottom (0) is the worst possible life and the top (10) the best possible life and asks them to give an indication as to where they feel they are on this scale. Other measures include general happiness measures that are not time bounded which generally correlate with life-satisfaction scores.

Experience (or affect) measures - Experience (or affect) measures perhaps are most closely aligned to the Benthamism view of well-being as they are concerned with how peoples feeling and emotions are affected by everyday events (DEFRA, 2011). Some of the measures to capture the affective status of people include, the Ecological Momentary Assessment (EMA) and Princeton Affect Time Use Survey (PATS). Those measures ask people for their experiences at random times in the previous day, a simpler method still is to 
ask about feelings relating to the whole day. Such simpler measures as EMA and PATS are useful and more appropriate for large scale general purpose social surveys where the luxury of a time use survey with diaries is not available (Diener et al,. 1985; Clark and Senik, 2011).

Eudemonic measures - Eudemonic concept-ions of subjective well-being differ significantly from the evaluative and affective components in that it goes beyond the respondent's reflective evaluation and emotional states to focus on functioning and the realization of the person's potential. According to Huppert et al. (2009) the "functioning" element of well-being embodies autonomy, competence, interest in learning, goal orientation, sense of purpose, resilience, social engagement, caring and altruism.

Simple life style and well-being of people - The end objective of pursuing voluntary simple life style is to promote and/or beef-up the welfare or well-being of people. As such, elements of simple life style largely determine the well-being of people. Self-Determination Theories depict that elements of simple life, like intrinsic motivation, are facilitated by the satisfaction of three elements of psychological well-being of people: the need for autonomy, competence, and relatedness, the experience of being close to other people (Deci \& Ryan, 2000). Moreover, social aspects of simple life style like Socializing and getting and giving social support is important precursors to wellbeing (Diener et al., 1985; Clark and Senik, 2011). Accordingly, absence of opportunities for social interaction leads to loneliness, which has significant negative effects on physical health and well-being. A sense of autonomous motivation powers job satisfaction, establish social contacts between workers themselves and between workers and clients, which in turn provide decision-making power and meaning in their work and/or their life too, and hence better position in their well-being (Deci \& Ryan, 2000).

Simple life style, well-being and public policy- There are bulk evidences supporting simple life style and well-being elements could be vital variables to promote the socio-economic progress of communities (Easterlin, 2013; Deaton, 2008). Promoting elements of Simple life style could be used as strategies for policy intervention towards promoting the well-being of people. those researchers conclude that as promoting aspects of simple life style could be used as an input to economic growth, national governments can provide the enabling conditions for well-being through better public services, urban planning that promotes relational leisure and diminishes commuting times, and a stronger social safety net (Easterlin, 2013; Deaton, 2008).

The importance of aspects and/or elements of simple life style and well-being on interventions aimed at enhancing production and productivity is well-depicted in (Turner et al., 1991; Vastamäki et al., 2004, and Paul, 2009). Those studies also raise instances where promoting well-being and socio-economic progress simultaneously involves trade-offs between different contributors to well-being, including freedom, opportunity, efficiency and equality (Okun, 1975). To best enable social well-being, each government needs to weigh up these tradeoffs, depending on what constituents value. On average, for example, the French probably value equality over freedom, whereas Americans prefer freedom over equality. The role of government policies in promoting and nurturing elements of simple life style is also explored in empirical and theoretical literature. For example, one important element of well-being, that is, autonomy could be promoted in two ways: firstly, by creating policies that provide people with more opportunities for choice in different domains of their lives, and, secondly, by removing unnecessary legal barriers and limitations in people's daily environments (Powdthavee, 2005). Government interventions can also be used to build meaning on people. One way to do so is providing opportunities to engage in meaningful activities is individually, socially, and economically beneficial. Interventions that provide meaning and self-efficacy in the workplace exist. Strategies like opting for open shared office spaces with natural lighting would enable to achieve those goals as it contributes to information sharing, to employee motivation, and to a sense of belonging to a community.

\section{Simple life style and happiness}

Simplicity is a way of life where people cherish minimal material life. Simple life style could be either voluntary or involuntary. Simplicity is said to be voluntary when it is consciously chosen, deliberate and 
intentional. In subsequent discussions, when we refer to Simple life style, we mean one which is voluntary simplicity. More often than not, simplicity is associated with as a path of regress than progress, where it is considered as primitive, backward looking. According to Duane Elgin, (2010), the dominant characterizations of simple life are biased and stereotypic in at least two ways. In all those views lies characterizing it as impediment to socio-economic progress: For one, crude or regressive simplicity-which takes autopian, back-to nature movement escaping the stresses of urban life in favor of living in the woods, or in the farm, or in recreational vehicle or in a boat. The second conception of simplicity is quite newer, cosmetic or superficial simplicity, and the characterization takes simplicity as opting a life style to be ecological friendly- using green technologies like fuelefficient cars, fluorescent light bulbs, and recycling. Accordingly, cosmetic simplicity puts green lipstick on our unsustainable lives to give them the outward appearance of health and happiness.

Historical sketch into the philosophy of simple life style - The primacy of the spiritual or intellectual life has been a central emphasis of most of the world's major religions and philosophies" (David Shi, 1985). Indeed, the virtue of a life of moderation appears throughout the Old Testament and the Gospel. The Socratic ideal of a middle road between sufficiency and excess appears in Proverbs: "Give me neither poverty nor wealth, but only enough." (Pro-verbs 30:8) Jesus was a radical in his rejection of material culture, teaching that undue esteem for material wealth opposed devotion to humankind and God. As he told his followers, "Do not store up for yourselves treasures on earth, where moth and rust destroy, and where thieves break in and steal. But store up for you treasures in heaven, where moth and rust do not destroy, and where thieves do not break in and steal. For where your treasure is, there your heart will be also" (Matthew, 6:19-21). The New Testament comments further on materialism: "If a man has enough to live on, and yet when he sees his brother in need shuts up his heart against him, how can it be said that the divine love dwells in him?” (John, 3:17). Indeed, ancient philosophical traditions from around the world have contributed to the modern simplicity ethic. Moral

UniversePG I www.universepg.com skepticism toward captivation by material wealth can be traced back to Ancient Greek wisdom. Socrates advocated a "golden mean between poverty and wealth" and considered virtue, not wealth, the measure of a person's merit (Ibid). The more extremes teachings of his student Plato would also have a lasting influence-especially the idea, in the words of Alan Kahan, that "the soul ranks above the body, and money beneath both" (Alan Kahan, 2010).

Plato's student Aristotle distinguished between the honorable making of money to satisfy needs and the detrimental accumulation of money as an end in itself (Ibid, 36). One of the Greek Philosophers by the name Xenophon depicts that wealthy are those who are able to limit their material interests. Judeo-Christian tradition added religious piety as a means of distancing oneself from concerns about material goods. They are firm to design a life style in conformity with the teachings of bible that places values on human dignity. Christians measure the worth of people not by the things they possess but by their being created in the image of God Luke 16:19-31. Hence, to measure worth by wealth, status, expensive possessions or other similar standards is to take away from the dignity of being created in the image of God. In the aftermath of industrial revolution and advent of capitalism, the notion of consumerism and material possession has got predominance in public life. Consumerism provokes the material glory of people, hence calling for acquisition of more material assets. Hence, the issue of simplicity came out of religious domain to take secular look and interpretation is a $20^{\text {th }}$ century phenomenon, where there emerged out quiet movement or voluntary movement in opposition to the new life style created on people by the capitalist classes, with the onset of consumerism getting instituted as cultural element of the people of U.S.A with the introduction of the American Dream. Beyond U.S.A. and Europe, the core tenets are preached and practiced in much of Asia, notably among those in India and Sri-Lanka deeply influenced by Gandhian ideals.

\section{What is voluntary simple life style?}

Voluntary simplicity involves both inner and outer condition. It means singleness of purpose, sincerity and honesty within, as well as avoidance of exterior clutter, of many possessions irrelevant to the chief purpose of 
life. It involves a deliberate organization of life for a purpose. Of course, as different people have different purposes in life, what is relevant to the purpose of one person might not be relevant to the purpose of another. It means an ordering and guiding of our energy and our desires, a partial restraint in some directions in order to secure greater abundance of life in other directions. It involves a deliberate organization of life for a purpose. The degree of simplification is a matter for each individual to settle for himself (Gershwin, 2010) but the meaning of the principle is "we can work less, want less, and spend less, and be happier in the process" (Linda Breen Pierce, 2000).

Academic interventions on simple life style - Early works that galvanized the voluntary simplicity movement were Small Is Beautiful: Economics as if People Mattered, (1973) by E.F. Schumacher and Voluntary Simplicity: toward a Way of Life that Is Outwardly Simple and Inwardly Rich, (1981) by Duane Elgin's. In his book, Schumacher criticized modern economic principles, where he rejected the economic system founded individual greed and limitless growth, calling instead for wisdom, which he believes translates into an economics of permanence:

Duane Elgin's deeply philosophical manual on the modern simplicity movement popularized the term "voluntary simplicity," often taken as a characterization of the modern simplicity movement. Voluntary Simplicity became a sort of Bible for the voluntary simplicity movement, and it remains a much-cited piece of literature. According to Elgin, to live voluntarily is to live conscientiously and deliberately, and to live more simply is to unencumber oneself in all aspects of life in order to "[meet] life face to face." David Shi defines simple life as a "shifting cluster of ideas" that elevates the ideal over the material. These ideas include the rejection of luxury, a respect for nature and preference for rural living, a desire for personal self-reliance, nostalgia for the past and skepticism toward modernity, conscientious rather than conspicuous consumption, and an aesthetic of plainness (Shi, David, 1985). According to Katherine M. Barton, (2014), voluntary simplifiers reject the ideal of consumerism: the notion that the acquisition of more material goods will make our lives better. Instead, they work less and focus on truly fulfilling experiences, such as relationships with family and friends, creating things, and the cultivation of holistic health. The goal of voluntary simplicity is not self-denial or austerity-on the contrary, voluntary simplifiers believe they are genuinely happier living with less (Katherine, 2014). Duane Elgin, (2010) defines simplicity based on a particular value of people. Summary of Elgan`s classifications of simplicity below.

A) Uncluttered simplicity: Simplicity entails avoidance of lives that are too busy, too stressed and too fragmented. Simplicity means cutting back on clutter, complications and trivial distractions, both material and non-material, and focusing on essentials-whatever those may be for each of our unique lives.

B) Ecological simplicity: Simplicity means to choose ways of life that touch the earth lightly and that reduce our ecological impact on the web of life. Hence, simplicity encourages us to connect with nature, the seasons and the cosmos. Ecological simplicity feels a deep reverence for the community of life on earth and accepts that the non-human realms of plants and animals have their dignity and rights as well the human.

C) Family simplicity: Simplicity means to place the well-being of one's family ahead of materialism and acquisition of things. Family simplicity affirms that what matters most in life is often invisible-the quality and integrity of our relationships with one another. Family simplicity is also intergenerational-it looks ahead and seeks to live with restraint so as to leave a healthy earth for future generations.

D) Compassionate simplicity: Simplicity means to feel such a strong sense of kinship with others. As such, it lives by the Ghanaian principle of "choose to live simply so that others may simply live". Hence, simplicity means feeling a bond with the community of life and being drawn towards a path of cooperation and fairness that seeks a future of mutually assured development for all.

E) Soulful simplicity: Simplicity means to approach life as a meditation and to cultivate our experience of direct connection with all that exists. By living simply, we can more easily awaken to the living universe that surrounds a d sustains us, moment by moment. 
F) Business simplicity: Simplicity means a new kind of economy is growing in the world with healthy and sustainable products and services of all kinds.

G) Civic simplicity: Simplicity means that living more lightly and sustainably on the earth requires changes in every area of public life-from public transportation and education to the design of our cities and workplaces. The politics of simplicity is also a media politics as the mass media are the primary vehicle for reinforcing-or transforming-the mass consciousness of consumerism. To realize the magnitude of changes required in such a brief time will require new approaches to governing ourselves at every scale.

H) Frugal simplicity: Simplicity means that, by cutting back on spending that is not truly serving our lives, and by practicing skillful management of our personal finances, we can achieve greater financial independence. Frugality and careful financial management bring increased financial freedom and the opportunity to more consciously choose our path through life. Living with less also decreases the impact of our consumption upon the earth and frees resources for others.

\section{Philosophical construct of economics of happiness}

Where is thatland of happiness and prosperity? Where is that part of world in which justice and fairness prevailed? Where is a fair world for all creatues- be it human kind or other lifes, the fauna and flora? Can we model for a utopia that provides us with 'yes' to these quests or remains a mere wish? If 'yes', how dear is the cost of securing that dream land? Indeed, these are not mere questons at all; also, inappropriate to dub a person with this point ideal. It is possible to establish a land where natural order triumph. One basic issue worthwhile in the construction of that dream land is that it is not an overnight project, and hence is a process. Moreover, the task is not like a conventional project with the quantity of resources, completion period and its serviceability years is estimated and /or forecasted. Also, the task requires the coordinated and continual effort of all humanity, of all present and future generations.

Nature and naturalism - If I may to define nature in a single word, I respond 'nature as a reality'. Nature is a supreme force meant to keeping the healthy workings of the world, where all life fetches fair share from natural peace. The fact that understanding nature and natural order requires an in-depth look into the visible and invisible world begs the fact that human-kind, the only animal with a reasoning power, is endowed with an ability to understand nature and hence privileged with all power and wisdom that enables it control its environment, and govern all other life on earth. When human kind is privileged with these powers, it is not for free; that is readiness to learn on nature and natural order, which I rather put it as one virtue of human characters. Disrespect to the rules of nature is the mother of all woes, in all departments of life: social, economic, political, and ecological at all levels. So, we can cleanse ourselves from all these evils once we get nature right: show the will and cour-age to live by natural laws.

Natural laws - Before narrating as to how upholding natural laws heals the causes of the suffering of humanity from biological to ecological to social to economic and/or political disease, let's depict the governing rules of nature. To the limits of my understandings, the rules of the game that govern the whole aspect of life, of all humanity at all time and/or places are: 'extremes are bad'; 'self-interest is inherent in human nature'; 'belief in natural justice' and 'the interdependence of all forms of life one another'. In a situation where natural laws upheld and set to work to mold people's behavior in decision making in whatever aspects of life: economic, social, political is natural order or naturalism. To the extent that we uphold the mentioned natural laws and their implied principles, we can ease the wider socio-economic, political, environmental/ecological problems of ours, and hence win up material and spiritual prosperity, ecological balance, fairness to all life, all of which are key elements that feature our dream land-our utopia.

\section{Understanding the concept of individualism}

How is Life defined in its social conception? Life in social conception is to mean in different settings in relationships: intra-personal or inter-personal; or interactions of people with the prevailing governing institutions. Hence, if people are socially alive, that means, they have to keep on making interactions. Under normal circum-stances, relationships are conditioned by rules, principles and institutions. Those 
rules and principles might have formal and informal existence. At least for our further analysis, we shall understand formality and informality as: whereas formal is to mean defined and codified in written form; informal means simply are unwritten or scattered. In general, the ultimate goal of those agreed upon codes of conducts, principles, value systems and norms are to promote the well-being of people and communities.

What governs the interactions of people in different settings? What is the motive of people in their relationships with themselves and others; how they behave in their social and economic transactions? In addressing all that, the pillar point would be understanding individualism. Hence, this chapter devotes to exploring if conventional individualism would hold in the context of eastern Ethiopia. Hence, conceptualizing individualism also holds. Moreover, attempts were made to depict the nature, workings and manifestations individualism in eastern Ethiopia.

Individualism redefined: individualism proper - No doubt that the end goal of every activities of a human kind is to maximize welfare and minimize pain. The key aspect here is as to how people gain pleasure. Not missing the point that conventional understanding of individualism is blurred, this part eyes an alternative to pleasure-pain divide in a bid to redefine individualism in more complete form, which I shall call it individualism proper. In contrary to the conventional definition of individualism, which focuses only on material assets, individualism proper connotes for both material and spiritual assets. Therefore, the motive behind individualism lies not in the realm of material gain only, but also in spiritual elements too. Therefore, the virtue of individualism rests upon material-spiritual calculus, instead of pleasure-pain calculus. Such an under-standing of individualism is the first step in redefining the notion of individualism, and hence understands what individualism proper is all about.

Explaining the material-spiritual gain requires clearing one bar: defining the possible interrelation between material gain and spiritual gain. It is my perspective that the possible links between material and spiritual gain may take three forms: competitive, complementary, or unrelated. When material satisfaction and spiritual satisfactions are intersected, material satisUniversePG I www.universepg.com faction may result into spiritual satisfaction, or the other way around. Where the two assets are unrelated, material gain do not compromise the spiritual gain or the other way around. There are times when material gains and spiritual gain may go in conflict, making the decision to locate oneself to material or spiritual element difficult. Under such instances, spiritual gains should get the priority: for one, spiritual satisfaction is enduring than material satisfaction; besides, spiritual gain is a pre-condition to material gain.

Dimensions of individualism Proper - To better understand self-interest, individualism proper establishes three interrelated dimensions: the socialistic dimension, moralistic dimension, and spatial \&time dimensions. The particular nature and implications of these dimensions integral in individualism proper endows individualism proper flexibility character, a trait conventional individualism seriously lacks. The flexibility character of individualism proper reveals itself in reasoning out and hence explains instances when people deliberately scarify their material interests to achieve pleasure. All in all, individualism proper widens the scope and motives of self-interest, resulting a broader and holistic understanding of individualism.

Socio-cultural dimensions - The relation assumption of conventional economics, which considers people are individualistic and hence act with no bothering about the social and cultural influences they may face, is far less realistic. Such a look relegates socio-cultural and religious elements in economic life of people, despite their importance. Moreover, this fallacy is the source of corrupt understanding of individualism. Sociocultural and religious values like: social norms, customs, cultures, beliefs, religion are powerful forces in governing the economic life of people. As human is a social animal, people can`t escape the influences of socio-cultural elements and considers all these components into consideration in their economic transactions. By sticking to these values, people are enhancing and sustaining their economic gains, which in fact amounts to self-interest. When we say people's conducts in economic life is shaped by socio-cultural and religious entities implies people values these entities. It is one's creed to his/her values that defines his/her individualistic nature. Possession of values is what defines the rationality of people, and how far people are loyal to 
their values would tell the extent of their individualistic character. In general, at the heart of individualism proper are Values.

The moralistic dimension - In the context of individualism proper, the aim of self-interest is to maximize material and spiritual gain. In pursuit of that, people always try to live up their values. As values are subjective, i.e. differ from people to people, we limit ourselves in the realm of moral values, which in fact shall be understood on grounds of humanity and equated accordingly. The moralistic dimension of individualism proper is its presumption that people are in many cases determined to living up their moral values. By doing so, they maximize their economic well-being. The key issue here is to look for how one's determination to surrender himself/herself to his/her values boost up material gain. People live up their values means they never go into conflict with themselves, meaning they gain inner peace. People live up their values means they fulfill the pre-requisites for success i.e. mental peace (Rahman, 2021). Once we are in such state of mind, we are able to develop the three ingredients of success in material life: free mind, vision, spiritual strength or courage. Hence, lust for once loyalty to values is individualistic move, and is instrumental for prosperity.

According to individualism proper, there is a room that self-interest and altruistic values go parallel. If one values altruism it is action for self-satisfaction, or fulfilling self-interest. By living up this value, an altruist person is self-interested as well; to borrow some words from Aristotle, altruism is rational selfishness. Therefore, if people seem to scarify their material life, that is a civilized retreat from material interest, for it is a retreat to comfortably and sustainably grab material gain.

Spatial and time dimensions - Socio-cultural environment is different among communities, and the values of people change with time. Hence, values are subject to variation among people belonging to differrent communities; their motives in their economic life i.e their self-interest changes through time too. Overall, sticking to individualism proper will address the roots of doubts on economic theory and practice. As such, economic theorizations and policy outcomes of individualism proper will scale-up the socio-economic welfare of people.

\section{Individualism proper promotes happiness of people}

Re-inventing economic theory and practice - Given the fact that orthodox economics, powered by conventional individualism, has been powerful in shaping economic theory and policy for long, the re-definition of individualism in the sense of individualism proper has a number of implications. In the academic arena the teaching of economics needs redesign in terms of content and approach. Content wise, a single economic theory and/or model might not work at all times, at all places. In terms of approach, deductive approach, the dominating school in main-stream economic thinking should at least be complemented by inductive reasoning, in the construction of economic theory and modeling. From policy perspective, individualism proper con-notes for a revision of the policy regimes mainly one size fits all principle of orthodox economics, calling for contextualizing economic policies to particular economies`socio-economic, political, religious and cultural contexts.

\section{Redefining life and civilizations}

Generally, in our drive towards that dream land, where all life can live in harmony, all it takes is not only wield resources to understand nature and its workings, but also readiness to bow-down to natural order. This in turn takes re-defining what life means and re-statement on the conception of human civilization.

Life re-defined - Let's for a while, ask our-selves: What life really mean for us or if we are living life to the fullest. No hesitations, that there is no a commonly shared answer. If I am supposed to say mine, I say that ability to breathe in and out do not justify a person as alive or dead. Living, as I under-stand, is the ability to sense and respond to our feelings: to be able to smell the fragrant or bad odor; to see not only the bold, also the tiny, even the invisibles. In its breadth and width, Life is to cry when one is supposed to cry; to laugh with what makes one laughter; to shout on what one considered as unfair, to suggest for right when one feel an action is wrong, and ultimately to be a voice for a voiceless. Hence, I call upon for a re-vision on the biological life-death definition, which considers ability to breath-in and breath-out respectively, of oxygen and 
carbon dioxide, a yardstick. Doing so has paramount importance in the whole process constructing our dream land. Life should be understood in line with understanding nature and natural order. In alternative words, living is to show a will to accept the reality and alive are those who at least exert efforts to understand nature and its rules. Such is the first step towards realization of our dream land. It is only when we are in such state of mind, meaning when are really alive, that we make inquiries on the nature and naturalism, and better understand the rules of nature.

A re-statement on the concept of human civilization - Human`s control over its environment has been taken a governing definition on what human civilization means. Indeed, this conception has nothing erratic. If we re-state this notion, it implicitly signifies understanding nature and readiness to abide by natural order as a pillar of human civilization. As civilization encompasses human state of thinking, efforts to dominate the hardships associated with natural environment and sophistication of governing principles in different aspects of life, it is crucial to depict on the understanding of the essentials of living and ultimately on what defines humanity and all its constructs at all levels-from familial-to-societal-to nation building. Hence, what makes of humanity is the basic element seeking address. I argue that what define humanity is one`s attempt and/or effort to understanding nature and natural order. Hence, people`s intelligence over nature and naturalism, the level of one`s courage to live by the rules and principles of nature are key ingredients of humanity. As a matter of fact, people are not the same in their level of understanding on nature, though they are equally endowed with a tool to do so- a reasoning power. As it is a solid fact that people vary in terms of their level of intelligence, so does societies/countries in terms of level of civilization. All in all, the right parameter to rely on to rank people in terms of intelligence and societies in terms of degree of civilization is the extent of intimacy they developed with nature.

\section{CASE STUDY ONE}

\section{Questioning the philosophical construct of ameri- can capitalism}

How Individualism proper promotes the welfare of people could be best illustrated by looking at the drawbacks of conventional individualism, as the weaknesses of individualism in its traditional sense are the strengths of individualism proper. The practical example as to how ill-defined individualism affects the people by depriving their economic and social enterprises can be seen by looking the American society.

Gauged by the scale of materialism, the Americans are the most individualistic people in the world; at the same time, they are the most altruist people on earth. The Americans cherish their individualistic values the secret of their economic prosperity. However, the American form of individualism is problematic, as it never fits the human nature. Indeed, what defines humanity is not only the material life, but also the spiritual life. The Americans ignored or missed the spiritual values at all. That is why they are not as prosperous socially as they are economically. I can say the American society is the most socially deprived one in the world. The American society does not allocate the necessary time needed for social business, making the society poor in social capital. The ill-defined individualism they worship has left the Americans to multitudes of problems. Over emphasizing the material world and ignoring the spiritual assets, the American society is most infected by the disease called- stress. Stress is the mother of not only every biological disease, but also of many social diseases ranging from drug abuse to robbery to serious crimes to terrorism. The institution of marriage, which is the basic construct in the formation of society and country, is most damaged by the notion of ill-defined individualism. According to one research, an average Americans dual income couples talk to each other only 12 minutes a day. Exaggerated attractions of Americans to material assets exposed them to arrogant businesses, which uses advertisements as a tool to play their game. Perhaps cheated by these advertisements, most Americans are affected by such habits that going to the markets for commodities which are not necessary to them. Over-purchase habits, especially in food items is seen as the average American family dumps down 25\% of the food stuffs it purchases. The per-head consumption of drug makes Americans the highest consumers of 'bads' in the world. 
A philosophy to convert economic prosperity into social stability is farfetched. Trying to treat social diseases by economic tablets will not bring a lasting cure except helping relieve the pains associated with the symptoms. The Americans may have a material resource to treat their disease. Yet they are treating simply the symptoms, not the causes of the diseases they are suffering from, which is stress. They don't get the cure unless they treat their mind sets and redefine what meant by self-interest in line with individualismproper. It is worthy to understand that self-interest, in the form the Americans understand, can potentially hamper economic progress. At the state level, government investment to treat social evils ranging from drug trafficking to robbery would create huge pressure on the economy. Richard Nixon, the president that ruled U.S .A between 1964 and 1974 has spent more than $\$ 1$ trillion to fight drug abuse. The U.S has the highest incarceration rate in the world, spending billions of dollars to care for prisoners. Fighting terrorism has cost U.S.A trillions of dollars in the past decade. An average American spends much time and more money to medication than anyone anywhere on our planet. More money spent for medication means fewer resources for productive investment; time reallocated from work places to hospitals means fewer hours on work, shrinking their income and productivity. By living up individualism proper they will not only bring social prosperity, but also enables them at least to keep up the economic prosperity they enjoyed already. All in all, if we understand and adhere to the principles of individualism proper, we are in a better position to recognize how to build our material, spiritual and emotional assets, promoting socio-economic prosperity.

How to achieve happy society? The process of building a happy society entails adhering strict principles to be lived by people and the institutions for governances of all departments of life: economic, social, political, and environmental. In this chapter, depicting the principles and preconditions for realizing a happy society will be formulated. Those principles are meant to shape the behaviors of people and their institutional structure of wider importance: economic, social, political and ecological, among others.

What it takes from people to realizing happy society? In the process of realizing our dream land two UniversePG I www.universepg.com interrelated elements seek an emphasis. The first one is people`s zeal to understand nature-its rules and working principles, which shall be taken a necessary condition. The second is people`s readiness to sense life to the fullest, what could be considered a sufficient condition. The former takes only endowing a deep sense of affection and readiness to lending the required time and energy to make inquiries into nature and its laws. The latter requires determination to practice the dictations of nature and bowing down to its rules, which should be considered as an essential virtue of human being.

How to physique the fabric of a happy society? Depicting the fabrics of a happy society is all about devising principles that better govern relationships among people in harmony promoting material and spiritual prosperity at all levels and different departments of life as depicted in subsequent discussions in this sub-section.

The economic order - What philosophy and/or principles govern people and communities in their economic life so as to better realize better material life? How should people behavior shall be molded so as to enjoy sustained material (economic) gains? Which philosophical line and/or principles shall be governing in the way to structure institutions for socio-economic importance? This part tries to address those and related concepts.

\section{What ought to govern the behaviors (motives) of people in their economic life?}

In molding the behaviors of people in their economic transactions, people better enjoy their material wellbeing if they cater to the principles of individualism proper and business simplicity. Understanding the concept of individualism is paramount to guarantee well-being of people. As depicted in section 3.2.1, individualism proper is a revisit on the conventional individualism so as forward to people principles to maximizing their material and spiritual gains or restated maximizing happiness. According to individualism proper, the way to achieve happiness is through material- spiritual calculus instead of pleasure-pain calculus, a philosophical line that makes up a conventional individualism. Hence, in contrary to the conventional definition of individualism, which focu- 
ses only on material assets, individualism proper connotes for both material and spiritual assets. Therefore, the motive behind individualism lies not in the realm of material gain only, but also in spiritual elements too.

In the process of realizing a happy society, business simplicity is another important philosophical line that people ought to adopt to achieve material and emotional well-being. Business simplicity means a new kind of economy is growing in the world with healthy and sustainable products and services of all kinds.

What should be the economic philosophy? A system of economic governance that appreciates the very nature of humankind, and takes into consideration of changing realities and/or unique features of people and communities is one which better promotes better wellbeing. Hence, designing the proper economic line-up that that guarantees sustainable economic growth, welfare of the mass, and ultimately promotes happiness has been the primary objective of economic science. Economists came up with different propositions so far, though the issue remained unanswered even today. To be specific, we are referring to economic ideologies. An economic ideology is a series of laws and principles that put in concerted order in a way that suit to makes up a framework that helps economic agents make economic decisions so as to optimize their utility.

At the heart of economic ideology is the philosophy it stood upon, which in turn defines the principles nature of a particular economic order to prevail accordingly. Since the antiquity, human kind has passed through five economic orders: Collectivism, Slavery, Feudalism, Socialism and Capitalism. It is important to note that except socialism and capitalism, the other were simply economic orders without philosophical line. Indeed, that is why socialism and capitalism widely regarded as ideological continuum. Alternative modals of production relations we know in history- collectivism, slavery, feudalism and socialism failed to work, in a sense of bringing about the welfare of the mass, for their workings was divorced from the inherent nature of human kind. By requiring people to be selfless, socialism underestimated and crushed the competitive force inherent in human nature, and that explains the collapse of socialism. Capitalism, with all its limitations, survives as a dominant economic philo- sophy for it better acknowledge the psychology of human being, which is self-interest.

However, it takes to understand that the philosophical line that the theory and practice of capitalism built upon has not been in conformity with the dictations of laws of nature. It is undeniable that the actual working of capitalism often passes the natural limit of selfinterest. Not to forget some of its merits, it is my conviction that the whole evils of capitalism are the byproducts of corrupt understanding on the concept of individualism. Hence, renovating the philosophical roots of capitalism is a milestone towards realizing an economic order that promotes collective happiness.

\section{The social order}

The social order in an ideal society where happiness and harmony of people preserved is one which opens little space for social evils. Such a social order involves with rewarding and punishment mechanisms in line with keeping calm and order in a particular society. More specifically, uncluttered simplicity is what matters to promote social harmony, where people avoid of lives that are too busy, too stressed and too fragmented and hence cutting back on clutter, complications and trivial distractions, both material and non-material, and focusing on essentials-whatever those may be for each of our unique lives. In those societies social chaos would get a cure by understanding the principles of nature. The most important principles appealing in this regard are 'extremes are bad' and 'belief in natural justice'. The former calls every one of us be moderate in our social transactionsbe it in family business, marriage market, social life, or companionship. By offering incentives and courage to behave in a modest and consistent manner, surrendering oneself to 'extremes are bad' balances our intrapersonal as well as inter-personal relations.

Belief in natural justice connotes that everyone is rewarded based on his/her effort. That would be crucial in setting accounts on the reward and/or punishment mechanisms in any relationship defined for whatever reasons. For example, as it invoke for principles of 'titfor-tat' and/or "do not do anything on others what you yourself dislike to happen on you", belief in 'natural justice' is a force that greatly shapes human conduct as it implicates for moral and ethical values that would be 
interpreted in implicating such traits powerful enough that help balance in case of overlapping interests or antagonism among individuals like: tolerance, make compromise, value for mercy, denial of revengeful actions, cooperation, loyalty, trustworthiness, and integrity, among others. The end result would be regulating relationships so as to give them pacific and enduring, creating harmony of interests while undertaking any social business.

\section{The political order}

A political system is perhaps a number one determinant of the well-being of people. In the process of building the economic and social order that makes up a happy society, it is up to the keen interest of political governance. To promote collective well-being of people, the political governance shall be structured in a way that promotes Good Governance Government. With the end objective of the political system is realizing a good governance government, the philosophical lines may vary depending on a number of circumstances including, but not limited to the following: $i$ ). the mindsets of governed; ii). Unique socio-economic and socio-cultural institutions; iii). Historical realities and contexts that in one way or the other conducted the nature of relationship between different segments consisting the larger mass of the population to be governed.

Having those mentioned elements, the political system has to value for the following three: value for free society; second, value for knowledge; third, enlightening the society. As its primary responsibility, the political system is one which one which promotes free minds, as it necessitates from the very nature of human kind, which is self-love. Political systems that deviate from those mentioned lines would be responsible for making peace scarcer and human grief abundant. The second aspect of a political system that promotes collective harmony of the ruled is value for knowledge. When I say knowledge is valued, I mean the principleknowledge is power-get strictly adhered in running the state machines and hence shape the course of public life. Hence, the political system should be committed where the education system is an instrument for behavioral change; also, it should free education from getting politicized. The political system has to be

UniversePG I www.universepg.com dedicated for meritocracy prevails to run the state machines, its institutions and the bureaucracy at large.

Under a system of political governance meant for collective harmony is mass enlightenment. The manifestations of that is public investment in endeavors that enhances the consciousness of citizens. Hence, the end objective of education would be beyond acquainting students' skills of writing and reading to make them understand subject matters. As such, the purpose of the education goes to make students value for the following: virtues of intellect like skepticism, sense of belongingness to societal and national affairs, cherish the principles of global citizenship, stand firm to defend the public quests, develop such skills like culture of reading. The education system is also one which discriminates the workings of moral laws over positive laws, so as to hold people morally and ethically responsible and disciplined accordingly. This in turn is paramount to promote traits of good characters like loyalty, integrity, tolerance, sense of brotherhood, loyalty to ones causes and public inter-ests. Moreover, the education system would be struc-tured in a way student grow up by exploring, under-standing and bow down to natural laws; informed of their cultural and historical backgrounds, among others.

In an effort to promote enlightenment, the government should commit resources so that art and artistic works get value. As art plays key instrument in enlightening societies, the government, apart from investing public resources, should provide special incentives for art sector and those involved in it. In line with the aforementioned goals of the political system, the objectives of government under the natural political order are three. The first would be working for the natural political order to prevail. Second, cultivate the ground so as naturalism hold. This is through fulfilling the preconditions prevalence of natural order requires, like advocate for natural laws, awakening the society to explore, understand and abided by natural laws. Third, as citizens are not equally literate and consciousness, narrowing this gap among citizenry should take key task of government.

\section{The ecological (environmental) order}

To promote ecological order, it takes to live by the principles of ecological simplicity. Simplicity means to choose ways of life that touch the earth lightly and that 
reduce our ecological impact on the web of life. Hence, simplicity encourages us to connect with nature, the seasons and the cosmos. Ecological simplicity feels a deep reverence for the community of life on earth and accepts that the non-human realms of plants and animals have their dignity and rights as well the human. Indeed, our time calls for ecological balance. Scientists put ecological imbalance as a 'root cause' of environmental problems.

\section{CASE STUDY TWO}

\section{Nature calling}

When I listen to the calls of nature, I hear a scream from all creatures. May be, we feel and hence lend our ears to the human grief only; the suffering of other life is however far from the table of discussions often times. However,unable to speak out their suffering in words doesn't mean the fauna and flora are passive; a deeper look into the world entails they rather are showing their sufferings in action, calling for a fair world where no life flourishes at the expense of the other; a world which is just not only for humankind, but also for all life; calling for pretty fair allocation of resources in a way that may not affect the health of other living things: big or small, born or unborn, of all the present and future generations. Upholding this principle connotes that any infliction against a single species is an infliction against all life and hence ecological balance would better prevails. All in all, once we get nature triumph; once we cherish nature and natural order; once we accept and bow-down to natural laws, then we are on the right path to our utopia,where joy, hope and prosperity in all aspects of life: be it social, economic, political and ecological is in abundances.

Yet, we can move one step behind to explore "why environmental crisis?", and the answer lies in disrespect for natural law- 'existence of every creature (species) is for.

\section{System of governance and policy regimes}

Key aspects that determine the nature of governance and course of development different from community to community depending of number of factors: institutional, structural, time variables, among others. Hence, the governance system, rather than governed by a one size fits all principle, shall consider the importance of psychological, attitudinal, and behavioral elements specific to particular communities. As a strategy to promote such governance systems and development approach in general requires making the local authorities to work on schemes that scale up the well-being of their communities. Indeed, national governments who are speaking of happiness and wellbeing are emphasizing the local level as the stage wherein they can be realized. For example, the UK government has strongly encouraged local governments to become a lead partner in enhancing wellbeing. The CWB Indicators Project in Australia was launched by the Local Government Association of Queensland, and many CWB measurement projects are managed by local governments (Kim and Lee, 2013).

\section{ACKNOWLEDGMENT:}

The completion of the present research study could not have been possible without the support and assistant of so many people whose names may not all be enumerated. Their supports are sincerely admiring and gratefully acknowledged.

\section{CONFLICTS OF INTEREST:}

The authors declare there are conflicts of interest.

\section{REFERENCES:}

1) Adler, A. (2009). Gross national happiness in Bhutan: A living example of an alternative approach to progress. Social Impact Research Experience Journal, 5(1), 1-137.

https://repository.upenn.edu/wharton research s cholars/74/

2) Alan Kahan, (2010). Mind vs. Money: x The War between Intellectuals and Capitalism, New Brunswick, NJ: Transaction Publishers.

3) Camfield, L., \& Skevington, S.M. (2008). On subjective well-being and quality of life. Journal of Health Psychology, 13(6), 764-775. https://pubmed.ncbi.nlm.nih.gov/18697889/

4) Clark, A.E. and C. Senik, (2011). "Is Happiness Different from Flourishing? Cross-Country Evidence from the ESS', Revue d'Economie Politique, 121(1), pp. 17-34.

https://econpapers.repec.org/article/cairepdal/red p 5f211 5f0017.htm 
5) David Shi, (1985). The Simple Life: Plain Living and High Thinking in American Culture, New York: Oxford University Press.

6) DEFRA, (2011). Life Satisfaction and other Measures of well-being In England, 20072011, Department for the Environment, Food and Rural Affairs.

7) Diener, E., R.A. Emmons, R.J. Larsen and S. Griffin, (1985). "The Satisfaction with Life Scale”, Journal of Personality Assessment, 49, pp. 71-75.

https://doi.org/10.1207/s15327752jpa4901 13

8) Diener, E. (2006). Guidelines for national indicators of subjective well-being and illbeing. Journal of Happiness Studies, 7(4), 397-404.

9) Easterlin, R. A. (1974). Does economic growth improve the human lot? Some empirical evidence. Nations and households in economic growth, 89, 89-125.

http://dx.doi.org/10.1016/b978-0-12-205050-3. 50008-7

10) Easterlin, R. A. (2013). Happiness, Growth, and Public Policy. Economic Inquiry, 51(1), 115.

http://dx.doi.org/10.1111/j.1465-7295.2012.00 $\underline{505}$

11) Gershwin, P. (2010). Simplicity and the city: understanding the voluntary simplicity - in Melbourne, Independent Study Project (ISP), Collection Paper 867/2010.

12) Hasan N. (2021). Political modernization in the developing countries: challenges and prospects, Asian J. Soc. Sci. Leg. Stud., 3(3), 41-48. https://doi.org/10.34104/ajssls.021.041048

13) Jackson T. (2008). The Challenge of Sustainable Lifestyle. [In:] State of the World 2008:
Innovations for a Sustainable Economy (2008). The World Watch Institute.

14) Katherine M. Barton, (2014). Listening to the Quiet Revolution: The Implications of Voluntary Simplicity for a Sustainable Society, Pomona College, and pp 1-89. https://core.ac.uk/download/pdf/70981043.pdf

15) Kim, Y., \& Lee, S. J. (2014). The development and application of a community well-being index in Korean metropolitan cities. Social Indicators Research, 119, pp 533-558.

https://link.springer.com/article/10.1007/s11205013-0527-0

16) Linda Breen Pierce, (2000). Choosing Simplicity: Real People Finding Peace and Fulfillment in a Complex World, Gallagher Press.

17) Rahman R. (2021). Conflict among indigenous communities and settler Bengali community of Chittagong hill tracts: is there a way to peace? Asian J. Soc. Sci. Leg. Stud., 3(2), 35-40. https://doi.org/10.34104/ajssls.021.035040

18) Seligman, M. E. P., \& Csikszentmihalyi, M. (2000). Positive psychology: An introduction. American Psychologist, 55, 5-14. http://dx.doi.org/10.1037/0003-066X.55.1.5

19) Stiglitz, J. E., Sen, A., \&Fitousi, J. (2010). Mismeasuring our lives: Why GDP doesn't add up. New York, NY: New Press.

20) Waldron, S (2010) Measuring Subjective Well-being in the UK, ONS working paper at http://www.statistics.gov.uk/cci/article.asp?ID=2 $\underline{578}$

21) Weerakoon T. (2020). Factors affecting diffusion of entitlement in consumption of scarce commodities: a psychological approach, $B r . J$. Arts Humanit., 2(6), 113-128. https://doi.org/10.34104/bjah.02001130128

Citation: Demiessie MG, Hossain MR, and Shirin S. (2021). The gateway to well-being and happiness: redefining individualism, voluntary simplicity and civilization, Asian J. Soc. Sci. Leg. Stud., 3(3), 59-74. https://doi.org/10.34104/ajssls.021.059074 @) 